\title{
Analisis Efisiensi Penggunaan Faktor-Faktor Produksi pada Peternakan Sapi Perah (Survei pada Peternak Sapi Perah, Kecamatan Pangalengan Jawa Barat)
}

\author{
Eficiency Analysis of Using Factor Production \\ on Smallholder Dairy Farming
}

\author{
Muhammad Hasan Hadiana ${ }^{1}$, Andre Rivianda Daud ${ }^{2}$, Annisa Wanda Utami ${ }^{3}$ \\ ${ }^{1,2}$ Staff Pengajar Fakultas Peternakan Universitas Padjadjaran \\ ${ }^{3}$ Mahasiswa Pascasarjana Fakultas Peternakan Universitas Padjadjaran \\ e-mail: hadiana@unpad.ac.id
}

\begin{abstract}
ABSTRAK
Kajian penggunanan faktor-faktor produksi telah dilaksanakan pada sektor peternakan sapi perah di sebuah koperasi susu dimana sektor peternakan sapi perah didominasi oleh peternakan skala kecil, betujuan untuk mengkaji kemungkinan peternak anggota koperasi mengingkatkan skala produksinya dengan meningkatkan penggunaan faktor-faktor produksi. Catatan dari sebanyak 1.251 anggota koperasi digunakan untuk menganalisis dan mengestimasi fungsi produksi peternakan sapi perah. Model Cobb Douglas digunakan sebagai persamaan regresi hipotesis yang menggambarkan bahwa produksi susu (Y) ditentukan oleh sejumlah faktor produksi. Sebuah dummy variable dimasukan ke dalam model regresi untuk menggambarkan adanya pengaruh perbedaan pelayanan koperasi dalam penanganan susu. Hasil analisis regresi menghasilkan dugaan persamaan dimana $\mathrm{Y}=6,123 \mathrm{X}_{1}^{0,704}$ $\mathrm{X}_{2}{ }^{0,249} \mathrm{X}_{3}{ }^{0,015} \mathrm{e}^{0,018 \mathrm{D}}$. Hasil analisis varian menunjukan adanya pengaruh signifikan variabel bebas atas $\mathrm{Y}$ secara simultan. Hasil t-test secara parsial membuktikan dua variabel pertama, yaitu jumlah sapi perah (X1)) dan pemberian pakan konsertrat, keduanya berpengaruh terhadap produksi susu. Analisi statistik untuk menguji kehomogenen fungsi produksi menerima hipotesis $\mathrm{H}_{0}: \sum \beta_{i}=1$. Dengan demikian dapat disimpulkan bahwa respon output berada pada tingkat pengembalian konstant (constant return to scale). Pada tingkatan ini memperbesar skala produksi dimungkinkan apabila tersedia faktor produksi dan biaya produksi diturunkan dengan menaikan output.
\end{abstract}

Kata kunci: Cobb-Douglas, dummy, return to scale.

\begin{abstract}
A study had been carried out on the dairy farming sector in a Dairy Cooperative which the business sector is dominated by smallholder farming. The objective of the study is to examine the possibility of the farmers increase their production scale by increasing the use of factors of production. Farm records from 1,251 members of the cooperative was analyzed to estimate the production function. The Cobb Douglas function is used as a hypothetical regression model that describes milk production $(Y)$ is determined several factor of production. A dummy variable (D) is included in the model to describe the influence of the difference in dairy service. The regression analysis results in the estimated equation where $Y=6,123 X_{1}^{0,704} X_{2}^{0,249} X_{3}^{0,015} e^{0,018 D}$. The variance analysis shows a significant effect of the explanatory variable on $Y$ simultaneously. Partial $t$-test $(P<0.05)$ verifies that the first two factors, namely herd size $\left(X_{1}\right)$ and concentrate feed $\left(X_{2}\right)$, each affects the milk production, while the effect of land $\left(X_{3}\right)$ and the dummy variable $(D)$ are insignificant. The statistical test of homogeneity the function accepts the null hypothesis of Ho: $\sum \beta_{i}=1$. It is concluded that the output response is at the level of constant return to scale (RTS), it means that increasing all factors proportionally increase in milk production with the same proportion. At this production level, increasing the scale of production depends on the availability of the factors as well as decreasing the cost of production by increasing output.
\end{abstract}

Keywords: Cobb-Douglas, dummy, return to scale. 


\section{PENDAHULUAN}

Pengembangan sektor peternakan sapi perah di Indonesia yang dirintis pada sekitar empat dekade yang lalu dibangun melalui sistem koperasi, dan merupakan salah satu negara diantara sejumlah negara di Asia yang mengembangkan dairy cooperatives dalam membangun industri persusuannya (FAO, 1994). Peternak sapi perah yang mengikuti program pengembangan usaha sapi perah (PUSP) merupakan anggota koperasi primer (KUD atau Koperasi Susu) yang perannya dalam sistem koperasi adalah beternak sapi perah dan menghasilkan susu segar, sedangkan peran lainnya seperti layanan input produksi serta penampungan dan pemasaran susu.

Keberadaan industri susu di Indonesia mempunyai kedudukan strategis untuk pembangunan sumber daya manusia melalui penyediaan sumber protein hewani. Prediksi konsumsi sapi pada tahun 2017 sebesar 977,67 ribu ton. Pada tahun 2018-2021, proyeksi permintaan susu sapi untuk konsumsi cenderung meningkat rata-rata $3,61 \%$ per tahun, sehingga total kebutuhan susu sapi pada tahun 2018 diperkirakan sebesar 1,01 juta ton, 2019 sebesar 1,05 juta ton, 2020 sebesar 1,08 juta ton dan 2021 sebesar 1,13 juta ton (Kementerian Pertanian, 2017). Pada tahun 2017, kekurangan pemenuhan ketersediaan susu mencapai 57,58 ribu ton. Pada tahun berikutnya, 2018 defisit meningkat dan diperkirakan terjadi kekurangan suplai susu sapi sebesar 102,27 ribu ton. Pertumbuhan produksi susu sapi dalam negeri sekitar $2 \%$ per tahun, sedangkan pertumbuhan konsumsi susu sapi lebih dari 5\% per tahun (Kementerian Pertanian, 2017). Hal ini menandakan bahwa terjadi ketidak seimbangan antara jumlah permintaan dan jumlah ketersediaan susu sapi. Pada Tahun 2016 tercatat produksi dalam negeri baru bisa mamasok tidak lebih dari $21 \%$ dari permintaan nasional, sisanya $79 \%$ berasal dari impor (Kementerian Pertanian, 2016).
Ditengah permintaan komodtas susu yang terus meningkat, sejak Tahun awal pengembanan Tahun 1979/1980 hingga dewasa ini kondisi peternakan sapi perah yang bergabung dalam koperasi susu mengalami banyak kendala dalam mengembangian skala produksi peternakan sapi perah. Peternak anggota umumnya memelihara ternak dalam jumlah yang tetep kecil, tidak memiliki basis lahan yang memadai untuk pakan hijauan yang maupun perluasan kandang. Sementara perubahan demografi, sosial dan ekonomi di beberapa wilayah sentra-sentra sapi perah menyebabkan persaingan antar sektor ekonomi mendorong harga-harga input cenderung meningkat (Hadiana, 2007). Di sejumlah wilayah kecamatan di Jawa Barat beberapa koperasi pranggota GKSI susu tidak aktif. Jika pada Tahun 1990 tercatat 37 buah koperasi, maka pada Tahun 2019 hanya tercatat 16 Koperasi (GKSI Jawa Barat, 2019)

Penyebab rendahnya produksi susu nasional terkait dengan masih rendahnya produktivitas para peternak yaitu di bawah 10 $\mathrm{kg}$ /hari (Yusdja, 2005), peramasalahan lainnya diantaranya menurut Kementrian Pertanian (2016) yaitu sulitnya ketersediaan pakan hijauan, mahalnya harga bahan baku pakan konsentrat, penurunan genetik sapi perah, dan manajemen peternakan yang belum proporsional dan efisien. Salah satu cara untuk meningkatkan produksi ternak sapi perah yakni dengan meningkatkan efisiensi faktor-faktor produksi yang digunakan dalam peternakan sapi perah. Keberhasilan usaha sapi perah salah satunya ditunjukkan dengan penggunaan faktor-faktor produksi yang efisien.

Studi ini secara spesifik bertujuan untuk mengetahui pengaruh faktor-faktor produksi secara parsial terhadap produksi susu, serta mengetahui tingkat efisiensi penggunaan faktorfaktor produksi berdasarkan ukuran pengembalian skala usaha (returns to scale) pada peternakan di wilayah koperasi susu. Kajian ekonomi produksi pada sektor onfarm peternakan sapi perah akan memberikan informasi sehingga 
dapat mengevaluasi pengaruh perubahan teknis maupun intervensi kelembagaan terhadap produksi dan penggunaan sumberdaya, di samping itu dapat membantu produsen peternak secara individu maupun kolektif melakukan penyesuaian-penyesuaian dalam penggunakan sumberdaya, merespon output untuk dapat mempengaruhi variabel-variabel ekonomi (Doll and Orazem, 1984).

\section{Materi dan Metode}

Metode penelitian yang dilakukan yaitu metode survei pada anggota koperasi KPBS Kecamatan Pangalengan yang tersebar di Desa Wanasuka, Ciasabuk 2, Citawa, Lembangsari, Cikembang, Mekar Mulya, Ciawi, Kebon Jambu, Warnasari, Wates, Citere, Babakan Kiara, Barusalam, Padarhurip, Los Cimaung, dan Gunung Cupu. Objek Penelitian ini, yaitu efisiensi penggunaan faktor-faktor produksi peternakan sapi perah rakyat. Penetuan lokasi penelitian ditentukan secara purposive atas dasar pertimbangan Kecamatan Pangalengan merupakan salah satu sentra peternakan sapi perah di Jawa Barat. Jumlah sampel yaitu sebanyak 1251 orang peternak. Jenis data yang digunakan berupa data primer dan data sekunder, teknik pengumpulan data menggunakan wawancara, dokumentasi, dan kuisioner.

Model analisis yang digunakan dalam penelitian ini adalah fungsi produksi CobbDouglas. Fungsi Cobb-Douglas dapat menganalisis hubungan antara faktor-faktor produksi terhadap produksi susu, dinyatakan sebagai berikut:

$$
\mathrm{Y}=\alpha \mathrm{X}_{1}^{\beta_{1}} \cdot \mathrm{X}_{2}^{\beta_{2}} \cdot \mathrm{X}_{3}^{\beta_{3}} \cdot \mathrm{e}^{\beta_{4} \mathrm{D}} \mathrm{e}^{\varepsilon}
$$

Keterangan :

$$
\begin{aligned}
\mathrm{Y} & =\text { Output atau Produksi susu (kg/hari) } \\
\mathrm{X}_{1} & =\text { Faktor produksi populasi ternak perah } \\
& (\text { ekor) } \\
\mathrm{X}_{2} & =\text { Faktor produksi pakan konsentrat } \\
& (\text { kilogram/hari) }
\end{aligned}
$$

$\mathrm{X}_{3}=$ Faktor produksi lahan yang digunakan $\left(\mathrm{m}^{2} /\right.$ hari $)$

$\mathrm{D}=$ Pengaruh layanan MCP (dummy)

$\alpha \quad=$ Koefisien konstanta

$\beta_{1}, \beta_{2}$ dan $\beta_{3}=$ Koefisien regresi penggunaan faktor produksi

$\beta_{4}=$ Koefisien variabel dummy pengaruh layanan MCP

$\mathrm{e} \quad=$ Bilangan eksponen (2,7182)

$\varepsilon \quad=$ Galat

Untuk mengestimasi koefisien regresi, persamaan fungsi Cobb Douglas di atas ditransformasi ke bentuk logaritma natural (Gujarati, 2006), sehingga diperoleh persamaan regresi berganda berbentuk logoritma (log-lin) sebagai berikut:

$$
\begin{aligned}
& \ln Y=\ln \beta_{0}+\beta_{1} \ln X_{1}+\beta_{2} \ln X_{2}+\beta_{3} \ln X_{3}+\beta_{4} \mathrm{D} \\
& +\varepsilon \text {. }
\end{aligned}
$$

dimana;

$\beta_{\mathrm{i}} \ln \mathrm{Xi}=\mathrm{Xi}^{\beta \mathrm{i}}$, dan

$\ln \beta_{0}=\alpha$ atau $\beta_{0}=\mathrm{e}^{\alpha}$

Untuk keperluan analisis regresi, semua data output dan faktor produksi diubah ke dalam bentuk logaritma. Sedangkan variabel layanan MCP, karena bersifat kualitatif (variabel dummy), menggunakan bilangan binner, yaitu $\mathrm{D}=1$ jika mendapat layanan $M C P$ dan $\mathrm{D}=0$ jika tidak. Analisis model regresi harus bebas dari penyimpangan asumsi klasik agar model dapat digunakan sebagai alat prediksi yang baik. Pengujian yang dapat dilakukan yaitu dengan uji multikolinearitas dan uji autokolerasi.

Untuk mengetahui pengaruh masingmasing variabel bebas terhadap produksi susu, diuji dengan t-statistik dengan menggungkan tarat nyata $0,05 \%$. Hipotesis statistik adalah $\mathrm{H}_{0}: \beta_{\mathrm{i}}=0$, artinya faktor produksi tidak ada pengaruh $X_{i}$ secara parsial terhadap produksi susu.

Pengambilan keputusan pada uji ini berdasarkan perbandingan antara $t$ hasil perhitungan dengan t-tabel. Apabila hasil perhitungan menunjukkan: 
a. $\mathrm{t}_{\text {-hitung }} \geq \mathrm{t}$-tabel, maka $\mathrm{H}_{0}$ ditolak, artinya faktor produksi memiliki pengaruh yang nyata terhadap produksi susu.

b. $\mathrm{t}_{\text {-hitung }}<\mathrm{t}$-tabel, maka $\mathrm{H}_{0}$ diterima, artinya faktor produksi tidak memiliki pengaruh yang nyata terhadap produksi susu.

Koefisien regresi ( $\beta$ ) yang dihasilkan menunjukkan elastisitas masing-masing faktor produksi. Jumlah dari elastisitas produksi $\left(\sum \beta_{i}\right)$ akan menjelaskan ukuran pengembalian skala usaha disebut returns to scale (RTS). Jika $\sum \beta_{i}=$ 1, maka skala pengembalian berjalan efisiensi karena presentase kenaikan output akan sama dengan presentase penambahan input (constant RTS). Jika, $\sum \beta_{\mathrm{i}}>1$, maka skala pengembalian usaha belum efisien karena presentase kenaikan output lebih besar dari presentase penambahan inputnya (increasing RTS), dan jika $\sum \beta_{\mathrm{i}}<1$, maka skala pengambilan usaha tidak efisien karena presentase kenaikan output lebih kecil dari presentase penambahan inputnya (decreasing RTS).

Pengujian statistik menggunakan uji $t$ dengan taraf nyata $(\alpha)=0,05$ atau tingkat kepercayaan $95 \%$ perlu dilakukan untuk menguji signifikansi ukuran returns to scale pada peternakan sapi perah.

Hipotesis statistik adalah $\mathrm{H}_{0}: \sum \beta=1$. Dimana $\sum \beta=\beta_{1}+\beta_{2}+\beta_{3}$. Peengujian hipotesis menggunakan formulasi:

$$
t-\text { hitung }=\frac{\sum \beta_{i}-1}{s e\left(\sum \beta_{i}\right)}
$$

Pengambilan keputusan atas hasil uji hipotesis adalah jika $\mathrm{T}_{\text {-hitung }}<\mathrm{T}_{\text {tabel }}$ maka terima $\mathrm{H}_{0}$.

\section{Lokasi Penelitian.}

Peternakan sapi perah berada di wilayah Kecamatan Pangalengan, berdasarkan letak memiliki luas wilayah 27.295 hektar dengan topografi berupa dataran, lereng atau punggung bukit, ketinggian rata-rata dari permukaan laut
1.446 meter. Responden peternakan sapi perah Kecamatan Pangalengan pada penelitian ini tersebar di beberapa desa diantaranya yaitu Wanasuka, Ciasabuk 2, Citawa, Lembangsari, Cikembang, Mekar Mulya, Ciawi, Kebon Jambu, Warnasari, Wates, Citere, Babakan Kiara, Barusalam, Padarhurip, Los Cimaung, dan Gunung Cupu.

\section{A. HASIL DAN PEMBAHASAN}

\section{Profil Peternak Sapi Perah}

Identitas peternak yaitu informasi yang menggambarkan karakterisrik peternak di daerah penelitian berupa informasi identitas umum responden dan latar belakang peternak yang berhubungan dengan usaha sapi perah. Karakteristik peternak yang diamati dalam penelitian ini meliputi tingkat umur peternak, pendidikan formal peternak, dan jenis kelamin peternak, secara lengkap tersaji pada Tabel 1 . Pengelolaan usaha sapi perah rakyat ditentukan oleh manajemen pengelolanya yaitu peternak. Untuk mengetahui gambaran tentang karakteristik peternak perlu diketahui informasi tentang latar belakang peternak yang berhubungan usaha pemeliharaan sapi perah rakyat.

Berdasarkan informasi pada Tabel 1, peternak didominasi oleh peternak laki-laki dengan presentase $86,3 \%$ dengan tingkat usia peternak didominasi oleh peternak dengan usia 31-45 tahun dengan presentase 43,17\%. Pendidikan peternak didominasi oleh tingkat pendidikan dasar walaupun terdapat pula peternak dengan tingkat pendidikan universitas sebanyak 11 orang peternak. Karakteristik peternak tersebut dapat berimplikasi pada manajemen usaha sapi perah karena manajemen berkaitan dengan sumber daya manusia, dari tabel tersebut menggambarkan masih besarnya potensi sumber daya manusia ditandai dengan usia peternak muda (31-45 tahun) yang merupakan usia produktif. Dari segi pendidikan sudah ada peternak yang mengenyam pendidikan hingga tingkat 
universitas, walaupun dominasi tingkat pendidikan masih ada di pendidikan dasar. Jenjang pendidikan memiliki korelasi positif dengan tingkat penerimaan inovasi, kemampuan untuk berempati, dan keinginan untuk maju. Diharapkan semkain banyaknya peternak di usia produktif dan meningkatnya tingkat pendidikan akan meningkatkan pengetahuan dan pengembangan usaha peternakan sapi perah di Kecamatan Pangalengan.

Tabel 1. Karakteristik Peternak Kecamatan Pangalengan $(\mathrm{n}=1251)$

\begin{tabular}{lcc}
\hline Variabel & $\begin{array}{c}\text { Jumlah } \\
\text { Peternak } \\
\text { (orang) }\end{array}$ & $\begin{array}{c}\text { Presentase } \\
(\%)\end{array}$ \\
\hline Jenis Kelamin & & \\
Laki-Laki & 1.079 & 86,3 \\
Perempuan & 172 & 13,7 \\
Tingkat Usia & & \\
16-30 tahun & 160 & 12,79 \\
31-45 tahun & 540 & 43,17 \\
46-50 tahun & 179 & 14,31 \\
lebih dari 50 tahun & 372 & 29,74 \\
Tingkat & & \\
Pendidikan & & \\
Tidak Sekolah & 33 & 2,6 \\
Dasar & 763 & 61,0 \\
Mengah & 444 & 35,5 \\
Universitas & 11 & 0,9 \\
\hline
\end{tabular}

\section{Produksi Susu}

Besarnya atau jumlah susu yang dihasilkan peternak per rumah tangga (RT) tergantung pada jumlah induk laktasi dan manajemen usahanya. Skala produktivitas dan skala usaha peternakan di Kecamatan Pangalengan tertera pada Tabel 2.

Berdasarkan pada Tabel 2, Banyaknya peternak dengan produktivitas sapi perah yang kurang dari $10 \mathrm{~kg} / \mathrm{ekor} / \mathrm{hari}$ realtif tinggi mencapai 39,7 persen. Sedangakan peternak dengan skala produktivitas di atas $15 \mathrm{~kg} / \mathrm{ekor} / \mathrm{hari}$ mencapai $20,6 \%$. Ukuran produktivitas mencerminkan efisiensi kemampuan teknis peternak, produktivitas penting untuk dipertahankan karena berhubungan dengan kesinambungan usaha mereka. Produktivitas susu setiap ekor sapi perah secara keseluruhan rata-rata adalah 11,79 $\mathrm{kg} /$ hari/ekor, dan rata-rata produksi susu per rumah tangga peternak adalah 36,51 $\mathrm{kg} /$ hari/peternak.

Tabel 2. Produksi Susu Peternak di Kecamatan Pangalengan $(n=1251)$

\begin{tabular}{lrr}
\hline $\begin{array}{c}\text { Produktivitas } \\
\text { per Ekor }\end{array}$ & $\begin{array}{c}\text { Total } \\
\text { (peternak) }\end{array}$ & Presentase \\
\hline & & \\
$0-10 \mathrm{~kg}$ & 497 & 39,7 \\
$10,1-14,99 \mathrm{~kg}$ & 496 & 39,6 \\
$15-20 \mathrm{~kg}$ & 240 & 19,2 \\
lebih dari $20 \mathrm{~kg}$ & 18 & 1,4 \\
\hline
\end{tabular}

\section{Pengunaan Faktor-Faktor Produksi}

Variabel bebas yang diamati adalah sejumlah faktor produksi yaitu pakan konsentrat, populasi ternak perah, luas lahan, dan satu variabel kualitatif yaitu pelayanan dalam penanganan susu. Rata-rata hasil produksi dari setiap unit usaha peternakan per hari dapat dilihat pada Tabel 3. Faktor-faktor produksi yang digunakan peternak diantaranya yaitu pemilikan sapi 3,09 ekor/peternak dari kisaran populasi 1-30 ekor/peternak. Berdasarkan informasi tersebut menggambarkan bahwa rata-rata populasi sapi perah per peternak di Kecamatan Pangalengan masih rendah.

Pemberian konsentrat rata-rata 23,40 $\mathrm{kg} /$ hari/peternak ata pada kisaran 2-143 $\mathrm{kg} /$ hari/peternak. Berdasarkan hasil pengamatan pakan konsentrat diberikan rata-rata sebanyak $7,55 \mathrm{~kg} / \mathrm{ekor}$. Penambahan konsentrat dalam ransum ternak merupakan suatu usaha untuk mencukupi kebutuhan zat-zat makanan, sehingga akan diperoleh produksi yang tinggi. Konsentrat juga dapat meningkatkan daya cerna bahan kering ransum dan pertambahan bobot badan (Holcomb dkk, 1984). 
Tabel 3. Rata-Rata Penggunaan Faktor Produksi pada Peternakan Sapi Perah Anggota Koperasi.

\begin{tabular}{llrr}
\hline Variabel & Satuan & Kisaran & Rata-Rata \\
\hline Faktor & & & \\
Produksi & & & \\
Populasi & Ekor & $1-30$ & 3,09 \\
Konsentrat & Kg/hari & $2-143$ & 23,40 \\
Lahan & $\mathrm{m}^{2}$ & $42-49700$ & 2614,56 \\
& & & \\
\hline
\end{tabular}

Luas lahan rata-rata $2.614,56 \mathrm{~m}^{2} / \mathrm{petemak}$ atau berada pada kisaran lahan 42-49.700 $\mathrm{m}^{2} /$ peternak. Ketersediaan lahan subur untuk penyediaan hijauan untuk sapi perah sangat penting karena $>50 \%$ dari kebutuhan sapi perah harus dipenuhi dari hijauan makanan ternak atau pakan sumber serat lainnya, makin luas penguasaan lahan yang dapat digunakan untuk usaha ternak makin terbuka peluang peternak meningkatkan skala usahanya.

\section{Jumlah Kepemilikan Sapi}

Untuk menjaga kontinuitas dari usaha ini maka perlu adanya bibit. Bibit yang dimaksud adalah bibit unggul yang mudah diperoleh, selain bibit yang unggul rasio sapi laktasi juga penting dalam produktivitas dan esfiensi suatu usaha.

Tabel 4. Skala Kepemilikan Sapi Laktasi

\begin{tabular}{clcc}
\hline \multirow{2}{*}{ No } & Kepemilikan & \multicolumn{2}{c}{ Jumlah } \\
\cline { 3 - 4 } & Sapi Laktasi & Peternak & Presentase \\
\hline 1 & 1 ekor & 330 & 26 \\
2 & 2 ekor & 391 & 31 \\
3 & 3 ekor & 244 & 20 \\
4 & 4 ekor & 126 & 10 \\
5 & $\geq 5$ ekor & 160 & 13 \\
\hline \multicolumn{2}{c}{ Total } & $\mathbf{1 . 2 5 1}$ & $\mathbf{1 0 0}$ \\
\hline
\end{tabular}

Pada Tabel 4 dapat dilihat bahwa rata-rata kepemilikan sapi perah produktif yaitu 3,09 ekor/peternak dengan rata-rata jumlah kepemilikan sapi laktasi 2,79 ekor/peternak. Berdasarkan penelitian Mandaka dan Hutagaol (2005), peningkatan jumlah kepemilikan sapi produktif sebesar $10 \%$ akan meningkatkan keuntungan usaha ternak sebesar 9,27\%.

\section{Pelayanan MCP}

\section{Tujuan Milk Collection Point (MCP)} adalah untuk meningkatkan kualitas dan mempercepat proses pendinginan susu setelah pemerahan, sehingga dapat meminimalisasi penurunan kualitas susu. Kegiatan yang bersinergi dengan MCP antara lain meningkatkan pengetahuan dan keterampilan peternak melalui pembinaan dan pelatihan yang berkelanjutan mengenai Standar Operasional Prosedur (SOP) pemerahan yang benar dan penyediaan peralatan pemerahan.

Petugas MCP memeriksa kualitas susu yang disetor, mengambil sampel susu, serta mengukur volume serta mencatatnya untuk diketahui peternak dan diarsipkan. catatan ini nantinya digunakan sebagai data untuk menjadi dasar dalam menentukan grade susu, harga, dan perhitungan pembayaran susu ke peternak (penyetor). Program MCP sudag mengadaptasi kartu anggota ber-barcode, komputer akan menemukan identitas peternak, dan catatan setoran susu. Sistem ini dapat mengurangi kesalahan petugas dalam pencatatan saat penyetoran susu.

Berdasarkan catatan koperasi dari 1.251 responden, mereka yang sudah mendapatkan pelayanan MCP yaitu 502 peternak (40\%). Meskipun inisiasi program ini dari koperasi dan Industri Pengolahan Susu (IPS) dalam rangka mendapatkan kuaitas susu yang lebih baik, namun sasaran dari program pelayanan ini adalah meningkatkan harga jual susu ditingkat peternak secara perorangan. Dengan harapan setiap peternak bergairah untuk mempertahankan kualitas susu karena mendapatkan harga yang tinggi, dalam jangka panjang diharapkan ada gairah meningkatkan skala produksinya.

Upaya menurunkan angka TPC (Total Plate Count) merupakan salah satu agenda utama dari program MCP ini. Selain diupayakan melalui 
peningkatan fasilitas layanan penampungan dan pengujian susu oleh koperasi, peternak juga dituntut dapat merubah kebiasannya serta melaksanakan SOP prosedur pemerahan secara lengkap (Hermawan, Sulistyati, dan Tasripin, 2015). Serangkaian tindakan yang dilakukan peternak yang mendapatkan pelayanan $\mathrm{MCP}$, diantaranya adalah menjaga selalu menjaga kebersihan milkcan dimana air bersih dan tempat pencucian difasilitasi MCP, memelihara sanitasi kandang, menerapakan SOP pemerahan, mempersingkat jeda waktu pemerahan dengan penyerahan/uji kualitas susu di MCP.

\section{Analisis Penggunaan Faktor Produksi}

Hasil pendugaan koefisien regresi menghasilkan koefisien sebagaimana pada Tabel 5, dengan demikian model logaritma (log-linear) persamaan matematis yang menjelaskan keterkaitan antara output dengan faktor produksi adalah seagai beriku:

$$
\begin{gathered}
\ln \mathrm{Y}=1,812+0,704 \ln \mathrm{X}_{1}+0,249 \ln \mathrm{X}_{2}+ \\
0,015 \ln \mathrm{X}_{3}+0,018 \mathrm{D}
\end{gathered}
$$

Jika persamaan (3) diubah kembali ke bentuk fungsi Cobb-Douglas, maka:

$$
\begin{aligned}
& Y=e^{1,812} X_{1}{ }^{0,704} X_{2}{ }^{0,249} X_{3}{ }^{0,015} e^{0,018 D} \\
& Y=6,123 X_{1}{ }^{0,704} X_{2}{ }^{0,249} X_{3}{ }^{0,015} e^{0,018 D}
\end{aligned}
$$

Koefisien determinasi persamaan regresi bernilai 0,691, dengan demikian dapat $69,1 \%$ dari variasi produksi susu dapat dijelaskan oleh keseluruhan variabel independen yaitu jumlah pemilikan sapi perah, konsentrat, lahan, dan pengaruh layanan MCP, sedangkan sisanya, $30,09 \%$ dijelaskan oleh faktor lain yang tidak terdapat pada model.

Adanya pengaruh variabel independen secara parsial terhadap variabel dependen diuji menggunakan t-statistik (Tabel 5). Variabel populasi $\left(\mathrm{X}_{1}\right)$ berpengaruh nyata $(\mathrm{P}<0.05)$ terhadap produksi susu, nilait-hitung lebih besar dari t-tabel $(\mathrm{t}=25,570>1,960)$. Demikian pula pakanl konsentrat $\left(\mathrm{X}_{2}\right)$ berpengaruh yang nyata terhadap produksi susu $(\mathrm{t}=10,051)$, sedangkan lahan $\left(\mathrm{X}_{3}\right)$ berpengaruh terhadap produksi susu pada taraf 10 persen $(\mathrm{P}<0.1)$. Variabel terakhir yaitu perbedaan layanan MCP tidak berpengaruh

\begin{tabular}{|c|c|c|c|c|c|}
\hline No & $\begin{array}{c}\text { Faktor } \\
\text { Produksi }\end{array}$ & $\begin{array}{r}\text { Kot } \\
\text { Re }\end{array}$ & $\begin{array}{l}\text { fisien } \\
\text { gresi }\end{array}$ & & t-hitung \\
\hline 1 & Populasi & $\beta_{1}$ & 0,704 & $* *$ & 25,570 \\
\hline 2 & Konsentrat & $\beta_{2}$ & 0,249 & $* *$ & 10,051 \\
\hline 3 & Lahan & $\beta_{3}$ & 0,015 & * & 1,751 \\
\hline 4 & $\begin{array}{l}\text { Dummy } \\
\text { MCP }\end{array}$ & $\beta_{4}$ & 0,018 & & 0,785 \\
\hline 5 & $\begin{array}{l}\text { Parameter } \\
\text { RTS }\end{array}$ & $\begin{array}{c}\left(\beta_{1+} \beta_{2+}\right. \\
\left.\beta_{3}\right)\end{array}$ & 0,968 & & 0,030 \\
\hline 6 & Konstanta & $\left(\ln \beta_{0}\right)$ & 1,812 & $* *$ & 24,239 \\
\hline 7 & $\begin{array}{l}\text { Koefisien } \\
\text { determinasi } \\
\left(\mathrm{R}^{2}\right)\end{array}$ & & 0,691 & & \\
\hline 8 & F-hitung & & $\begin{array}{r}697,5 \\
02\end{array}$ & & \\
\hline 9 & $\begin{array}{l}\text { Darwin- } \\
\text { Watson }\end{array}$ & & 1,849 & & \\
\hline
\end{tabular}
terhadap produksi susu.

Tabel 5. Hasil Analisis Pendugaan Koefisien Regresi.

Keterangan:

**berpengaruh nyata pada taraf $\alpha=5 \%$

* berpengaruh nyata pada taraf $\alpha=10 \%$

$\mathrm{t}$-tabel $=1,960(\alpha=0,05 ; \mathrm{db}=1246)$.

Sejauh ini kebijakan koperasi dalam program MCP adalah mendorong peternak untuk menghasilkan susu dengan angka TPC seminimal mungkin (Hermawan, dkk. 2017). Idealnya keberadaan program MCP juga berdampak memunculkan kesadaran peternak untuk meningkatkan skala produksi susu segar seiring dengan peningkatan kualitas dan harga susu sehingga pendapatan yang diterima peternak lebih besar lagi. Diduga insentif harga yang diterima peternak dari peningkatan kualitas susu belum memiliki daya tarik yang signifikan yang direspon peternak meningkatkan produktivitas usahanya.

\section{Analisis Efisiensi Penggunaan Faktor- Faktor Produksi}

Secara teknis efisiensi penggunaan faktor produksi dapat dilihat dari (Returns to Scale, 
RTS). Tujuan analisis RTS adalah untuk mendapatkan ukuran respon produksi atas perubahan semua faktor produksi secara proporsional, sehingga dapat diketahui apakah penambahan faktor produksi untuk memberbesar skala produksi sebaiknya dilakukan atau tidak. Nilai RTS dapat diketahui dengan menjumlahkan koefisien elastisitas masing-masing faktor produksi. Bentuk logaritma analisis regresi fungsi Cobb-Douglas dapat digunakan sebagai nilai elastisitas produksi (Soekartawai, 2003). Jika jumlah nilai koefisien elastisitas faktor-faktor produksi sama dengan satu $\left(\sum \beta=1\right)$, maka produksi berada pada kondisi constant return to scale.

Hasil analisis menunjukkan jumlah semua nilai koefisien elastisitas faktor-faktor produksi (populasi, konsentrat, lahan) adalah 0,968. Namun hasil pengujian mendapatkan nilai thitung lebih kecil dari t-tabel (Tabel 5), maka secara statistik menerima hipotesis nol $\sum \beta \mathrm{i}=1$, dengan kata lain bahwa peternakan sapi perah anggota koperasi berada pada kondis constant RTS. Pada kondisi ini setiap penambahan faktor produksi akan diikuti dengan peningkatan hasil produksi dengan proporsi yang sama, misalkan peternak meningkatkan penggunaan semua faktor produksi secara proposrional sebesar $10 \%$ maka hasil produksi susu akan meningkat sebanyak $10 \%$. Pada penelitian sebelumnya yang dilakukan oleh Alla A, Yeti L.P, Deni L (2015) di Jawa Barat, pada peternak dengan populasi lebih besar dari lima ekor, jumlah nilai koefisien faktor-faktor produksi 0,428 dan 0,794 untuk populasi kurang dari lima ekor dan hasil uji-t menghasilkan kesimpulan yang menerima hipotesis constant RTS. Dalam kondisi ini keputusan untuk meningkatkan skala produksi susu melalui penambahan penggunaan faktor-faktor produksi dapat dilakukan apabila peternak menghadapi pasar dimana kenaikah harga susu lebih tinggi dibandingkan dengan harga-harga faktor produksi.

\section{B. KESIMPULAN DAN SARAN}

\section{Kesimpulan}

Berdasarkan hasil pengamatan dan pembahasan maka dapat disimpulkan bahwa faktor produksi yang berpengaruh nyata terhadap output pada peternakan sapi perah adalah banyaknya ternak, pakan konsentrat, dan lahan pakan hijauan, sedangkan perbedaan pelayanan MCP tidak berpengaruh terhadap produksi susu. Tingkat penggunaan faktor-faktor produksi berada pada constant returns to scale, dalam kondisi ini pengembangan skala produksi peternakan sapi perah anggota koperasi akan memberikan insentif kepada peternak jika kenaikan harga output (susu) lebih besar dari kenaikan harga-harga faktor produksi.

\section{Saran}

Beberapa saran yang dapat diberikan sebagai berikut:

1. Pada kedaan skala pengembalian konstan (constant return to sclae), produksi susu dapatditingkatkan melalui peningkatan penggunaan faktor-faktor produksi dengan pertimbangan kenaikan harga produksi susu lebih tinggi dari kenaikan harga faktor produksi.

2. Berdasarkan analisis, penambahan populasi dan konsentrat secara signifikan dapat meningkatkan produksi susu sehingga diharapkan peternak dapat meningkatkan populasi dan pemberian konsentrat untuk meningkatkan produksi susu. Optimalisasi penggunaan lahan juga dapat meningkatkan produksi susu dengan cara pemanfaatan lahan yang ada untuk hijaun dan penambahan populasi sapi perah.

\section{DAFTAR PUSTAKA}

Akoso, B. T . 2012. Budidaya Daya Sapi Perah. Pusat Penerbitan dan Percetakan Unair (AUP). Surabaya. 2. 
Badan Pusta Statistik. Direktori Perusahaan Pertanian Peternakan. 2019. ISSN: 26544555.

Doll J.P and Orazem, F. 1984. Production Economics. Theory with Applications. 2end Edition. John Willey and Sons.

FAO, 1994. Dairy Development through Cooperative Structure. Experiences in Dairy Devepompent. World Animal Reviewer.

Gujarati. 2006. Dasar-Dasar Ekonometrika Jilid I. Erlangga. Jakarta.

Hadiana, M.H. 2007. Dampak Faktor Eksternak Kawasan terhadap Efisiensi Usaha Ternak Sapi Perah. Program Pascasarjana. Universitas Padjadjaran.

Hermawan, Sulistyari.M, Firman. A. 2017. Produktivitas Usaha Ternak Perah Skala Kecil di KPBS Pangalengan. Prosiding Seminar Nasional Pengembangan Peternakan Berkelanjutan.

Holcomb G, H. Kiesling and G. Lofgreen. 1984. Digestibility of Diets and Performance by Stress Feed Varying Energy and Protein Level in Feedlot Receiving Program. Livestock Research Beef and Cattle Growers Shorts Course. New Mexico State University, Mexico.
Mandaka S dan M. P Hutagaol. 2005. Analisis Fungsi Keuntungan, Efisiensi Ekonomi dan Kemungkinan Skema Kredit Bagi Pengembangan Skala Usaha Peternakan Sapi Perah Rakyat Di Kelurahan Kebon Pedes, Kota Bogor. Jurnal Agro Ekonomi, Volume 23 No. 2, Oktober 2005: 191-208.

Soekartawai. 2003. Teori Ekonomi Produksi: Pokok Bahasan Analisis Fungsi CobbDouglas. Raja Grafindo Persada. Jakarta.

Yusdja, Y. 2005. Kebijakan Ekonomi Industri Agribisnis Sapi Perah di Indonesia. Pusat Analisis Sosial Ekonomi dan Kebijakan Pertanian Volume 3 No 3, September 2005. Bogor. 261.

Kementerian Pertanian. 2017. Outlook Susu Komoditas Pertanian Sub Sektor Peternakan. Pusat Data dan Sistem Informasi Pertanian Sekertariat Jenderal-Kementerian Pertanian. ISSN: 1907-1507.

Kementerian Pertanian. 2016. Outlook Susu Komoditas Pertanian Subsektor Peternakan. Pusat Data dan Sistem Informasi Pertanian Sekertariat Jenderal-Kementerian Pertanian. ISSN: 1907-1507. 